\title{
Radiocarbon Dates on Saiga Antelope (Saiga tatarica) Fossils from Yukon and the Northwest Territories
}

\author{
C.R. HARINGTON ${ }^{1}$ and JACQUES CINQ-MARS ${ }^{2}$
}

(Received 13 June 1994; accepted in revised form 30 August 1994)

\begin{abstract}
Saiga antelopes (Saiga tatarica), presently confined to Central Asia, spread westward to England and eastward to the Northwest Territories of Canada during the late Pleistocene. Two saiga cranial fragments from the Yukon Territory and the Northwest Territories have yielded radiocarbon dates of $13390 \pm 180$ and $14920 \pm 160$ B.P. respectively. Thus, saigas occupied the easternmost part of their known Pleistocene range toward the close of the Wisconsinan glaciation. Saigas probably died out between 13000 and 10000 years ago in North America because of rapid changes in climate and plantscapes occurring about that time, as former steppe-like terrain was replaced by spruce forest and tundra.
\end{abstract}

Key words: saiga antelope, Saiga tatarica, Yukon Territory, Northwest Territories, late Pleistocene, vertebrate fossils

RÉSUMÉ. La saïga, ou antilope des steppes (Saiga tatarica), qu'on ne trouve actuellement qu'en Asie centrale, couvrait pendant le pléistocène tardif un territoire s'étendant vers l'ouest jusqu'à l'Angleterre et vers l'est jusqu' aux Territoires du Nord-Ouest du Canada. Deux fragments de crâne de saïga venant du Territoire du Yukon et des Territoires du Nord-Ouest ont donné par radiodatation un âge de $13390 \pm 180$ et de $14920 \pm 160 \mathrm{BP}$ respectivement. La saïga occupait donc la région la plus orientale de son territoire connu au pléistocène, vers la fin de la glaciation du Wisconsin. La saïga a probablement disparu il y a environ 13000 à 10000 ans en Amérique du Nord en raison des changements rapides dans le climat et les paysages végétaux qui se produisirent à cette époque, alors que la pessière et la toundra remplacèrent le terrain steppique.

Mots clés: saïga, Saiga tatarica, Territoire du Yukon, Territoires du Nord-Ouest, pléistocène tardif, fossiles de vertébrés

Traduit pour la revue Arctic par Nésida Loyer.

\section{INTRODUCTION}

Saiga antelopes are relatively small $(60-70 \mathrm{~cm}$ shoulder height), light (26-32 kg), buff-coloured antelopes (Bannikov, 1963; Sokolov, 1974). Their inflated, proboscis-like noses apparently allow them to breathe efficiently in arid, dusty conditions, each nostril containing a sac lined with mucous membranes (Thenius and Hofer, 1960; Hillaby, 1969). Males bear spindly, lyrate horns with rings, whereas females usually lack horns (Fig. 1). Their coats are heavy and wool-like, so they can adapt readily to cold conditions. When alarmed, they can reach speeds up to $75 \mathrm{~km} / \mathrm{h}$, making it difficult for predators to catch them, although wolf packs have been known to hunt them successfully (Bannikov, 1963).

Mating begins in late November when males collect harems and engage rivals in violent combat. Because males eat little during the rut, they face winter in poor condition, and only the strongest survive. Females frequently bear twins, enabling saigas to expand their populations quickly when conditions permit. Such fecundity—combined with an ability to cover distances of 80 to $120 \mathrm{~km}$ or more per day and a lack of permanent territory-apparently allowed the species to spread rapidly from the steppes of central Asia to western Europe and North America when suitable habitat became available there during the late Pleistocene.
Presently saigas are confined to dry steppes and semideserts and feed on xerophytes. Studies of their stomach contents show that grasses are most abundant, with prostrate summer cypress (Bassia scoparia) second, lichens third, and Ephedra and Artemisia, in minor quantities (Bannikov et al., 1961). The climate governing their present range is extremely continental, with warm summers in which mean July temperatures reach $22^{\circ}-28^{\circ} \mathrm{C}$. Winters are severe: mean January temperatures

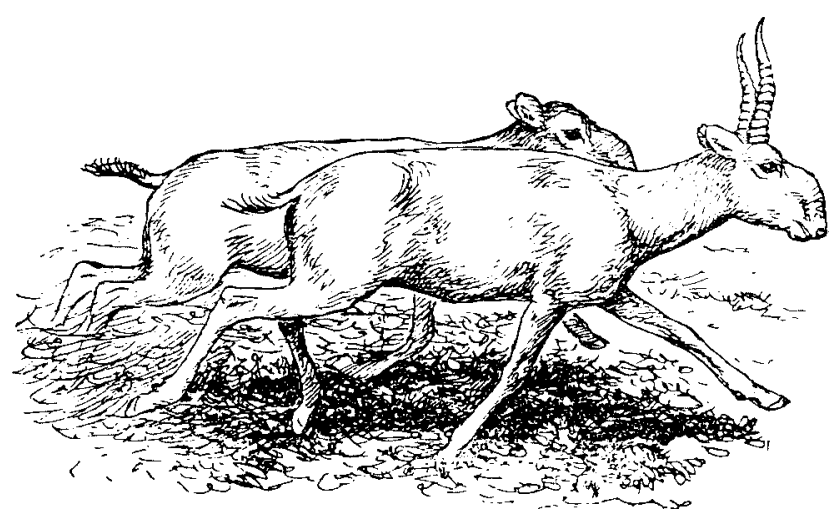

FIG. 1. Saiga antelopes (Saiga tatarica) - male with horns in front, female behind. Note lightness of build, expanded nasal region and lyre-shaped horns of male. Sketch by A.N. Komarov (Heptner et al., 1988: Fig. 147).

\footnotetext{
${ }^{1}$ Canadian Museum of Nature (Paleobiology), Ottawa, Ontario K1P 6P4, Canada

${ }^{2}$ Canadian Museum of Civilization, Archaeological Survey of Canada, Hull, Quebec J8X 4H2, Canada

(C) The Arctic Institute of North America
} 
are from $-6^{\circ}$ to $-16^{\circ} \mathrm{C}$, and temperature can drop to $-45^{\circ} \mathrm{C}$. Precipitation is low, varying from 10 to $30 \mathrm{~cm}$ per year. Most importantly, snow cover is thin. Evidently saigas cannot tolerate deep snow; even $20 \mathrm{~cm}$ of snow makes foraging and travelling difficult for them. Deep snowfalls contribute to winter die-offs and migration; yet saigas need snow to supply their winter water requirements (Sher, 1968; Vereshchagin and Baryshnikov, 1982).

Harington (1981) provides a history of the discovery of Saiga fossils in North America, beginning with a partial cranium with horncores collected by O.C. Kaisen and O.W. Geist at Lillian Creek near Livengood, Alaska in 1930, and ending with the partial cranium with a right horncore collected by D.C. Linck on Usuktuk River, Alaska in 1978. Linck's find, which yielded a radiocarbon date of $37000 \pm$ 990 B.P. (GSC-3050) (Harington, 1980, 1981), was the ninth Saiga fossil recorded from North America. Since then, Porter (1988) recorded a posterior cranial fragment with horncores and a right humerus of saiga from Lost Chicken Creek, Alaska, and the first author (Harington, 1991) has examined the following, previously unreported saiga specimens in collections of the University of Alaska Fairbanks Museum: (1) a posterior cranial fragment with right horncore (UA-V54-196); (2) a right orbital region with attached horncore (UA-V-54-970); and (3) a left orbital region with the proximal half of a left horncore (no data; perhaps it is part of UAV-54-970). The first two specimens are from Lost Chicken Creek, Alaska.

This paper describes a new saiga specimen from Bluefish Cave III, the first record of this species from the Yukon; provides the results of recently acquired radiocarbon analyses of the Bluefish Cave and Baillie Islands, Northwest Territories specimens (Harington, 1980, 1981); compares measurements of the Yukon and Northwest Territories specimens with other Pleistocene saiga fossils from North America and the former Soviet Union; and discusses the paleoenvironmental significance of the finds.

\section{SITES AND STRATIGRAPHY}

\section{Bluefish Cave III, Yukon Territory}

The saiga fossil was collected in 1985 by a field crew under the direction of Jacques Cinq-Mars at Bluefish Cave III (MgVo-3), one of three small caves located $54 \mathrm{~km}$ southwest of the village of Old Crow $\left(67^{\circ} 08^{\prime} \mathrm{N}, 140^{\circ} 47^{\prime} \mathrm{W}\right)$, within the northernmost portion of the Keele Range (Fig. 2). The caves (actually small caverns or rockshelters $3-4 \mathrm{~m}$ wide) lie at the base of a series of prominent limestone ridges situated approximately $250 \mathrm{~m}$ above the right bank of the Bluefish River, a north flowing tributary of the Porcupine River. They consist of erosional remnants of an ancient karst system, similar to a number of others that have recently been identified in the same general area (Cinq-Mars and Lauriol, 1985), and have produced, in addition to a small series of artefacts and other cultural signals (found primarily in Caves I and II), thousands of vertebrate remains. The pertinent Cave III chronostratigraphic context is relatively straightforward and similar in many ways to that of Caves I and II: a late Pleistocene, poorly differentiated loess unit containing remains of fishes, amphibians, birds and mammals (including the saiga) is overlain by a Holocene, cryoclastic rubble and humus unit characterized by an impoverished fauna of extant taxa (Cinq-Mars, 1979, 1982, 1990; Cinq-Mars and Morlan, in press; Morlan, 1989; Morlan and Cinq-Mars, 1982).

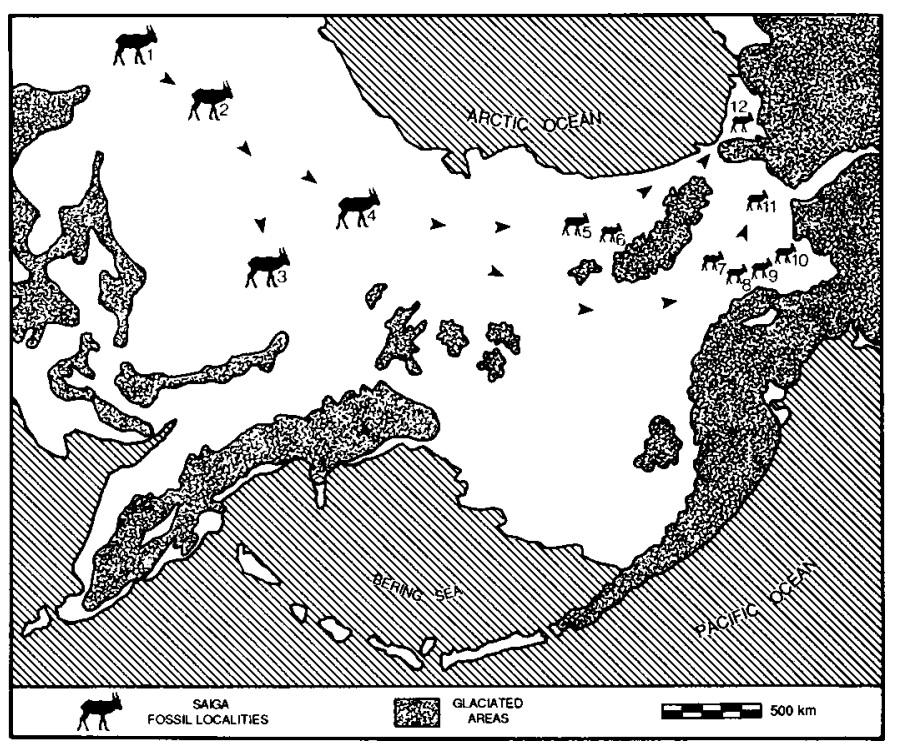

FIG. 2. Generalized map of Beringia during the peak of the last (Wisconsinan) glaciation showing localities of saiga (Saiga tatarica) fossils (numbered silhouettes). Arrows indicate possible routes used by saigas moving from western Beringia (eastern Siberia) to eastern Beringia (Alaska, Yukon and Northwest Territories) via the broad, exposed plains of the Bering Isthmus (right of centre). The Beringian shorelines arbitrarily follow the $-180 \mathrm{~m}$ isobath; glaciated areas are shaded and land is white. Map modified from Hopkins (1972) and Harington (1981). Saiga fossil localities: 1. Near Kayaga Lak, Lena Delta, Russia (Sher, 1968). 2. Bolshoi Lyakhov Island, New Siberian Islands, Russia (Sher, 1968). 3. Near Kolymskaya, Kolyma River, Russia (Sher, 1968). 4. Ayon Island, Chukotka, Russia (Agadjanian, 1979). 5. Kuk River, Alaska (Harington, 1981). 6. Usuktuk River, Alaska (Harington, 1980). 7. Lillian Creek near Livengood, Alaska (Frick, 1937). 8. Cripple Creek near Fairbanks, Alaska (Harington, 1981); Gold Hill near Fairbanks, Alaska (Harington, 1981). 9. Banner Creek near Big Delta, Alaska (Harington, 1981). 10. Lost Chicken Creek, Alaska (Porter, 1988; Harington, field notes 1991). 11. Bluefish Cave III, Yukon Territory (this paper). 12. Baillie Islands, Northwest Territories (Harington, 1971, 1981; this paper).

A yet-to-be-published series of AMS radiocarbon dates (see Dating section) dealing with (mostly) faunal evidence from all three caves indicates that the Bluefish Caves aeolian deposit dates back to between 25000 and 10000 years ago, at which time it was more or less conformably replaced by the Holocene rubble-rich humus. Pollen diagrams obtained from Caves I and II are characterized by three important zones that closely replicate the sequence which has been developed for neighbouring areas of northern Yukon and interior Alaska: a herbaceous tundra zone, a subsequent Betula (birch) zone dating to about 14000 years ago and, finally, a Picea (spruce) zone dating to 10000 years ago (Ritchie et al., 1982). Bluefish Cave III is the only site in North America where a saiga fossil has been excavated in situ, in a clearly recognizable stratigraphic context. The specimen was associated with a 
broad range of species including (among the larger mammals) woolly mammoth (Mammuthus $\mathrm{cf}$. M. primigenius), horse (Equus lambei), caribou (Rangifer tarandus), bison (Bison cf. B. priscus), muskox (Ovibos moschatus), and mountain sheep (Ovis dalli) (Fig. 3; see also Cinq-Mars 1990, Table 1).

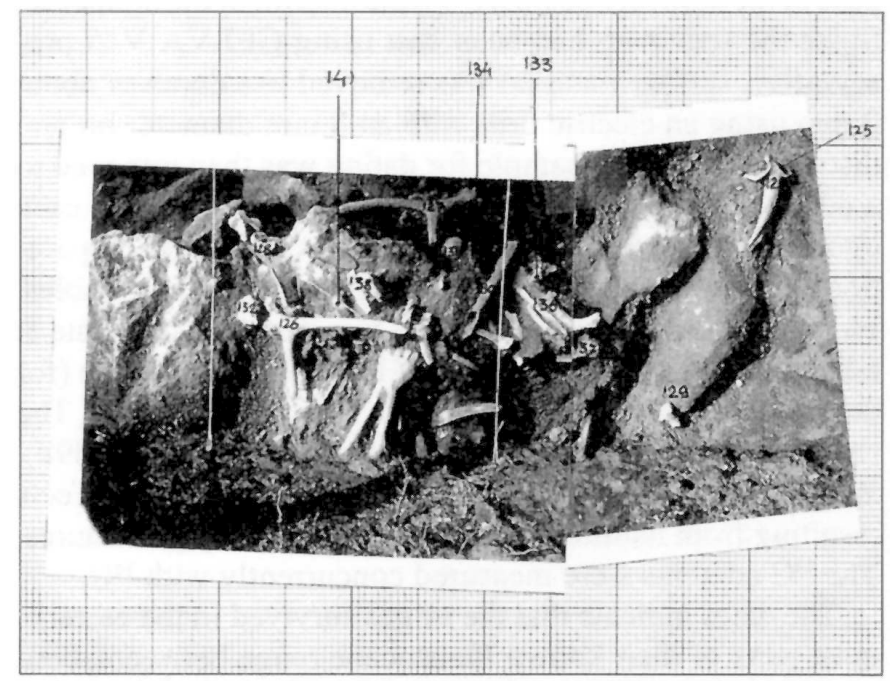

FIG. 3. Overhead photo mosaic of a portion of Bluefish Cave III bone bed taken during the 1985 excavation. Note saiga specimen (\# 125) in the upper right corner in relation to other nearby Pleistocene mammal fossils.

\section{Baillie Islands, Northwest Territories}

This specimen was collected (with other vertebrate remains) by J.G. Fyles of the Geological Survey of Canada on a beach surface near the eastern tip of Baillie Islands $\left(70^{\circ} 35^{\prime} \mathrm{N}\right.$, $128^{\circ} 06^{\prime} \mathrm{W}$ ) (Fig. 2). The beach specimens suggested two successive environments: a cool loess steppe setting as indicated by remains of woolly mammoth (Mammuthus primigenius), horse (Equus sp.), caribou (Rangifertarandus), bison (Bison sp.), saiga antelope (Saiga tatarica) and muskox (Ovibos moschatus); and a marine coastal environment as indicated by remains of bowhead whale (Balaena mysticetus), ringed seal (Phoca hispida) and polar bear(Ursus maritimus), perhaps mainly Holocene in age (Harington, 1971). However, a radiocarbon date on a bison hornsheath from this locality yielded an age of $1810 \pm 90$ B.P. (I-5407). This date, along with other evidence from Cape Bathurst on the adjacent mainland, suggests that an enclave of wood bison (Bison bison athabascae) occupied the Beaufort Sea coast recently (Harington, 1980, 1990). It was difficult to reach a firm conclusion about the geological age of the saiga fossil from a study of regional stratigraphy (Fyles, 1966). In the vicinity of Baillie Islands, uniform fine sand and silty sand about one metre thick overlie marine clay containing wood and marine mollusc shells that lie beyond the limit of radiocarbon dating. The bones collected were inferred to have washed out of the bank, probably from silty sand. The sand and silty sand unit could have been deposited during an interstadial or interglacial interval prior to the last glaciation (Rampton, 1988), or it could be a proglacial deposit formed during the last glaciation. The late Wisconsinan age of the saiga fossil (see Dating section) supports the last interpretation, although Rampton (1988, Fig. 19) evidently did not recognize late Wisconsinan sediments in that area.

\section{DESCRIPTION AND COMPARISON OF SPECIMENS}

Both Yukon and Northwest Territories specimens are similar in appearance (Fig. 4), and differ in no important way from the same parts of Pleistocene and Recent skulls previously examined (Table 1; Harington, 1981). Therefore they are referred to the saiga antelope (Saiga tatarica (Linnaeus), 1776, an artiodactyl belonging to the Family Bovidae Gray, 1821, and the Genus Saiga Gray, 1843) mainly on the basis of the roundish (in cross-section), short, slender, solid horncores with longitudinal grooves, and a slight, posterolateral curve. Further, the profile of the post-horn region is relatively straight (Gromova, 1968).

The Yukon fossil (MgVo-3-85-125) consists of most of the left frontal region (with pedicel, complete left horncore, superior part of the orbit, and large ovate supraorbital foramen) and small parts of the right frontal (beyond the characteristically raised, not fully fused frontal suture) and parietal bones. Most breaks on the specimen are relatively sharp and angular, with a small crack ascending from near the frontal suture toward the base of the pedicel. No cut or gnaw marks are apparent. The surface sculpture is well preserved, and some details of the inner surface of the braincase are clear. The colour of the fossil is buff to grayish brown (Fig. 4A).

The Northwest Territories specimen (NMC 12090) consists of much of the left frontal region (with pedicel, complete left horncore, superior and posterior edges of the orbit with characteristically grooved lateral margin extending ventrally on the inner surface to the optic foramen, and the large ovate supraorbital foramen) and a large part of the parietal. The frontoparietal suture is more open than that of the Yukon fossil. Surface sculpture is well preserved, including a fine network of "rootlet-tracks," suggesting that it had once been buried near a grassy surface. The colour of the specimen varies from buff to deep reddish-brown. In places the broken margins of the specimen are rounded and slightly burnished, probably as a result of beach erosion (Fig. 4B).

Both specimens are considered to represent adult male saigas because of the presence of large, clearly fluted horncores and the condition of the sutures. However, NMC 12090 may have been slightly younger than the other because of its more open frontoparietal suture.

The Yukon and Northwest Territories specimens are quite similar in size, except that the latter (despite its apparently younger age) is estimated to be nearly $9 \mathrm{~mm}$ wider across the pedicels and about $7 \mathrm{~mm}$ greater in horncore circumference. The Canadian fossils are close to the means for grouped specimens from the Pleistocene of North America and the former Soviet Union (Table 1). It is worth noting that combined North American and former Soviet Union Pleistocene 


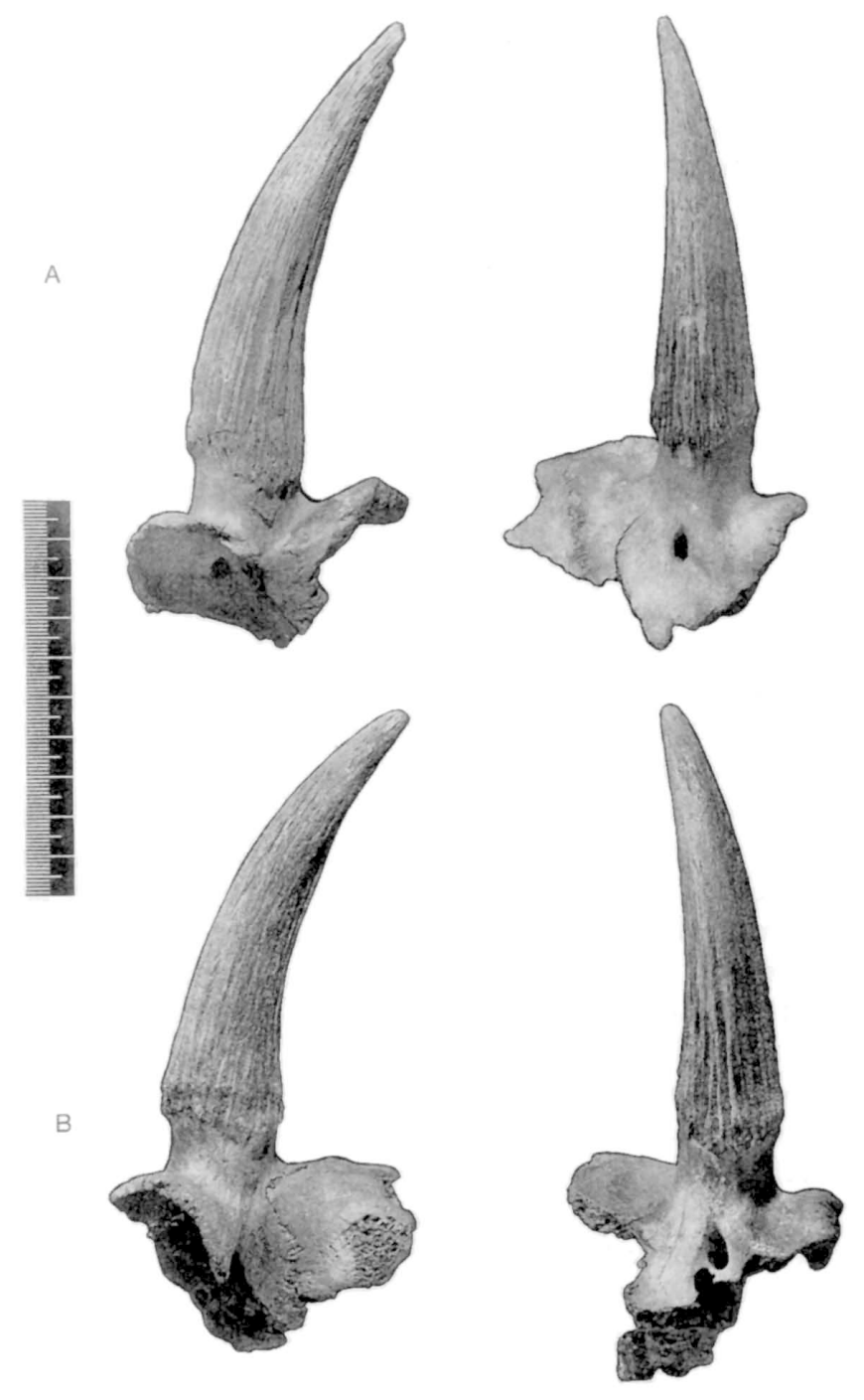

FIG. 4. Saiga antelope (Saiga tatarica) horns with attached cranial bones from Bluefish Cave III, Yukon Territory, MgVo-3-85-125 (A: left side and front views) and Baillie Islands, Northwest Territories, NMC 12090 (B: left side and front views). AMS radiocarbon dates on bone samples yielded ages of $13390 \pm 180$ B.P. (RIDDL-279) and $14920 \pm 160$ B.P. (Beta-25119, ETH-3898) respectively.

saiga specimens are larger on the average in mastoid width, horncore circumference and particularly horncore and metapodial length than Recent specimens, suggesting that Pleistocene saigas were larger than Recent ones (Harington, 1981: Tables 1,2). Perhaps such a size reduction is related to impoverishment of saiga range during the Holocene.

\section{DATING}

Both specimens were radiocarbon dated using the accelerator mass spectrometry (AMS) technique, whereby only a few grams of bone are needed. A small sample of bone was cut from the Yukon specimen about $25 \mathrm{~mm}$ below the interior opening of the supraorbital canal. This was submitted to E. Nelson of the Radio-Isotope Direct Dating Laboratory
(RIDDL) of Simon Fraser University, and processed and radiocarbon dated according to the procedures described in Vogel et al . (1991). The specimen yielded an age of 13390 \pm 180 B.P. (RIDDL-279).

Approximately $2.5 \mathrm{~g}$ of bone was removed from the Northwest Territories specimen by drilling upward into the base of the horncore pedicel from the interior of the braincase. Since the specimen had been cast using GELVA V15 preservative, surface material was removed to a depth of about $2 \mathrm{~mm}$ using an electric drill with an $8 \mathrm{~mm}$ diameter bit and discarded. The bone sample for dating was then removed to a depth of about $24 \mathrm{~mm}$. Clean drill bits were used for each operation. Chemical pretreatment and AMS target preparation were performed at Beta Analytic Inc. (Coral Gables, Florida). The AMS measurements were made in triplicate at ETH (Eidgenossiche Technische Hochschule) in Zurich (for details of the process see Harington and Morlan, 1992). The resulting date is $14920 \pm 160$ B.P. (Beta-25119, ETH-3898), and has been adjusted for total ${ }^{13} \mathrm{C}$ fractionation effects resulting from natural processes and laboratory procedures. The ${ }^{13} \mathrm{C}$ contents were measured concurrently with ${ }^{14} \mathrm{C}$.

The dates indicate that the saigas survived in the easternmost parts of their known Pleistocene range between about 15000 and 13000 years ago toward the close of the last (Wisconsinan) glaciation. The date on the Baillie Islands specimen confirms the first author's suggestion that it is of Wisconsinan, rather than pre-Wisconsinan, age (Harington, 1981).

\section{DISCUSSION}

The available paleobiological evidence indicates that saigas reached the eastern extremity of their known Pleistocene range between about 15000 and 13000 years ago (Fig. 2; contra the implication of Kahlke, 1991), and the westernmost extremities even later; e.g., a horncore from a unit dated to $13000 \pm 200$ B.P. at the Grotte de la Salpêtrière, in the Gard, France (Crégut-Bonnoure and Gagnière, 1981); a calcaneum from Gough's Cave in Cheddar, England yielding a radiocarbon age of $12380 \pm 160$ B.P. (OxA-463) (Currant, 1987); and Crégut-Bonnoure's (1992:182) statement "Its disappearance at about 10500 B.P. is roughly contemporaneous in southeast and southwest France." No references are given supporting this date, however.

Presumably the steppe-like range that allowed saigas to flourish in Europe and North America was replaced by markedly different plant regimes between 13000 and 10000 years ago. The first vegetation to occupy the Tuktoyaktuk region (between Baillie Islands and Bluefish Caves) after the Mackenzie valley tongue of the Laurentide ice disintegrated about 13500 years ago was an open, herbaceous tundra. Sagebrush (Artemisia), grasses and other herbs, perhaps representative of steppe-like conditions, are relatively high in summary pollen percentage diagrams about this time (Zone 1) from Twin Tamarack and M Lake sites (Ritchie, 1984, Table 7, Figs. 13, 16, 17). In northwestern North America, incursion of dwarf birch began about 14000 years ago, and 
TABLE 1. Cranial measurements of Pleistocene adult male saigas (Saiga tatarica) found in the Yukon and Northwest Territories compared to those found in other North American sites and in the former Soviet Union.

\begin{tabular}{|c|c|c|c|c|c|c|c|c|}
\hline \multirow[b]{2}{*}{ Specimens } & \multicolumn{8}{|c|}{ Measurements $(\mathrm{mm})^{1}$} \\
\hline & 1 & 2 & 3 & 4 & 5 & 6 & 7 & 8 \\
\hline $\begin{array}{l}\text { Bluefish Cave III, Yukon } \\
\text { (MgVo-3-85-125) }\end{array}$ & $73.4^{\mathrm{e}}$ & $98.8^{\mathrm{e}}$ & 26.0 & 24.6 & 95.0 & 32.2 & 28.4 & 131.0 \\
\hline $\begin{array}{l}\text { Baillie Islands, N.W.T. } \\
\text { (NMC 12090) }\end{array}$ & $74.0^{\mathrm{e}}$ & $108.0^{\mathrm{e}}$ & 26.4 & 24.3 & 102.4 & 34.0 & 27.3 & 132.0 \\
\hline $\begin{array}{l}\text { Pleistocene, North America, } \\
\text { (Harington, 1981: Table 1, } \\
\text { including above specimens) }\end{array}$ & & & & & & & & \\
\hline $\mathrm{M}^{2}$ & 71.2 & 101.3 & 28.2 & 26.1 & 106.6 & 34.3 & 29.8 & 130.0 \\
\hline $\mathrm{OR}^{2}$ & $68.0-74.0$ & $94.0-108.0$ & $25.2-33.9$ & $24.0-30.0$ & $95.0-125.0$ & $31.4-39.5$ & $26.2-35.5$ & $108.0-149.0$ \\
\hline $\mathrm{N}^{2}$ & 4 & 4 & 5 & 5 & 5 & 5 & 5 & 4 \\
\hline $\begin{array}{l}\text { Pleistocene, former USSR, } \\
\text { (Harington, 1981: Table 1) } \\
\text { M }\end{array}$ & 71.7 & 100.0 & 29.5 & 26.9 & 103.4 & 35.8 & 31.6 & 148.5 \\
\hline OR & $66.3-74.0$ & $90.9-112.5$ & $28.1-32.0$ & $24.9-28.8$ & $93.0-114.0$ & $32.5-41.1$ & $27.0-36.8$ & $122.0-164.0$ \\
\hline $\mathrm{N}$ & 5 & 6 & 8 & 8 & 7 & 7 & 8 & 4 \\
\hline
\end{tabular}

1 1. Minimum width of cranium immediately posterior to horncore bases. 2. Minimum width across lateral faces of horncore pedicels. 3. Anteroposterior diameter of horncore at pedicel. 4. Mediolateral diameter of horncore at pedicel. 5. Circumference of horncore at burr. 6. Anteroposterior diameter of horncore at burr. 7. Mediolateral diameter of horncore at burr. 8. Length of horncore (burr to tip along anterior surface). ${ }^{\mathrm{e}}$ Estimated measurements based on doubling the half widths.

${ }^{2} \mathrm{M}=$ mean; $\mathrm{OR}=$ observed range; $\mathrm{N}=$ number of specimens in sample.

spruce forest advanced over much of the region not dominated now by tundra some 10000 years ago (Matthews, 1982).

Saigas occupied eastern Beringia prior to the Late Wisconsinan, as well. A radiocarbon date on a right horncore of Saiga tatarica from Usuktuk River some $150 \mathrm{~km}$ south of Barrow, Alaska yielded a radiocarbon date of $37000 \pm 990$ B.P. (GSC-3050) (Harington, 1980). This date suggests that saigas lived in northern Alaska during the relatively warm Middle Wisconsinan interval, perhaps from about 50000 to 25000 years ago (Harington, in press). Additional radiocarbon dates on saiga remains from northwestern North America will be required to indicate the likelihood of the species' occupying the region during the peak of the last glaciation (perhaps 25000 to 15000 years ago). It is also possible that saigas underwent a similar radiation with expanding steppe conditions during the previous Illinoian/Saale) glaciation (Harington, 1981; Kahlke, 1992).

The fossil evidence suggests that saigas followed a two pronged route into eastern Beringia: first, along the coastal lowlands bordering the Beaufort Sea (Kuk River, Usuktuk River, Baillie Islands) and second, up the Yukon River valley (e.g., Lillian Creek, Fairbanks area, Banner Creek and Lost Chicken Creek), with a short detour up the Porcupine River valley to the vicinity of Bluefish Caves (Fig. 2). It is surprising that no saiga remains have been reported in the large Sixtymile fauna of the Yukon, when at least three specimens are known from Lost Chicken Creek only $55 \mathrm{~km}$ to the west. Nor has the species been reported from 72 productive Pleistocene vertebrate localities in the Dawson City area of the Yukon. Despite the fact that saigas apparently reached the Bluefish Caves area by moving up the Porcupine River valley (the route from the Yukon River valley would have been relatively smooth, probably reaching elevations no higher than $700 \mathrm{~m}$ asl), there is no evidence of saiga fossils among thousands of Pleistocene vertebrate remains from more than 150 sites in Old Crow Basin, approximately 100 $\mathrm{km}$ north-northeast of the caves (Harington, 1989). Will saiga fossils be found eventually at Sixtymile, Dawson and Old Crow Basin, or had the species reached a topographic and ecologic barrier consisting of forbiddingly high, rough country lacking appropriate steppe-like range? Was it here, near the present Alaska-Yukon border, that saigas were blocked from penetrating southward to the heartland of North America?

Saiga antelopes are usually considered to be valuable paleoenvironmental indicators of steppe-like vegetation, generally low, flattish terrain, rather arid climatic conditions, and shallow winter snow cover (Sher, 1968; Harington, 1981). It is worth recognizing, however, that "northern" saigas may have been more adaptable than previously thought, because: 1) their putative steppe-like range in northern Siberia, Alaska, Yukon and Northwest Territories during the Pleistocene was peppered with "unfamiliar" arctic plant species; 2 ) in reaching the vicinity of Lost Chicken Creek they probably had to travel over unusually rough ground, reaching altitudes of at least $1240 \mathrm{~m}$ asl, perhaps closer to $1500 \mathrm{~m}$ asl considering the lowered sea levels of the last glaciation; 3) they endured 
fewer frost free days and longer periods of winter darkness.

What might have been most damaging to the survival of these northern saigas were occurrences of sudden winter warming, creating tough ice crusts that severely checked herd movement and made foraging difficult. Information regarding such widespread deep-snow, icing catastrophes depleting muskox and caribou herds in the Canadian Arctic Islands and eastern Greenland during the winters of 1953-54 and 1966-67 and earlier can be found in Bruggemann (1954), Gray (1987), Harington (1961), MacDonald (1954), Meldgaard (1986), and Vibe (1954, 1967). Formosov (1963) provides a broad, general discussion of the subject. Indeed, perhaps deeper snow (Guthrie, 1982; Vereshchagin and Baryshnikov, 1982), as well as the more frequent and more extensive occurrence of ice-crusting during the marked climatic warming between 13000 and 10000 years ago, was a more important proximal factor in the demise of the Pleistocene megafauna of northwestern North America than has been recognized previously.

\section{ACKNOWLEDGEMENTS}

The first author is grateful to Dr. J.G. Fyles (Geological Survey of Canada) for collecting the Baillie Islands saiga fossil, and for donating it and other specimens from the area to the Canadian Museum of Nature collections. Dr. Murry Tamers (Beta Analytic Inc., letter of September 6, 1988) kindly supplied details on procedures used to radiocarbon date the specimen (NMC 12090), and Jerry Fitzgerald (Canadian Museum of Nature) provided assistance with the sampling procedure. The second author wishes to acknowledge the support of all institutions and agencies which, over the years, have made possible his work at the Bluefish Caves, namely the Social Sciences and Humanities Research Council of Canada, the University of Toronto, the Archaeological Survey of Canada, Canadian Museum of Civilization, and the Polar Continental Shelf Project, Energy Mines and Resources Canada. Thanks should also be extended to Dr. E. Nelson (Simon Fraser University) for providing continuing advice and support on matters regarding the dating of the Bluefish Caves deposits, as well as to all colleagues, field assistants and Old Crow residents who have in one way or another facilitated this research. Finally, we wish to acknowledge the pertinence and usefulness of the comments from the reviewers of this paper, an anonymous one as well as Dr. D.M. Hopkins (University of Alaska, Fairbanks), and Dr. J.V. Matthews Jr. (Geological Survey of Canada).

\section{REFERENCES}

AGADJANIAN, A.K. 1979. New data on the fossil mammalian fauna of Chukotka. In: Shilo, N.A., ed. Stratigraphy and paleobiogeography of the Pacific Ring's Cenozoic. Proceedings of the XIV Pacific Science Congress, Khabarovsk. Vol. 2. 164-166.

BANNIKOV, A.G. 1963. Die Saiga-Antilope (Saiga tatarica L.). Wittenberg: A. Ziemsen Verlag.
BANNIKOV, A.G., ZHIRNOV, A.V., LEBEDEVA, A.S., and FANDEYEV, A.A. 1961. Biologiya saigaka. Moscow: Izdatel'stvo Selskokhozyaistvennoi Literatury, Zhurnalov i Plakatov.

BRUGGEMANN, P.F. 1954. Wildlife observations made in 1954 at Eureka, Fosheim Peninsula, Ellesmere Island, N.W.T. Unpubl. report. Available at the Canadian Museum of Nature (Paleobiology), Ottawa, Ontario K1P 6P4, Canada.

CINQ-MARS, J. 1979. Bluefish Cave I: A late Pleistocene eastern Beringian cave deposit in the Northern Yukon. Canadian Journal of Archaeology 3:1-32.

1982. Les grottes du Poisson-Bleu. Geos 11:19-21.

1990. La place des grottes du Poisson Bleu dans la préhistoire béringienne. Revista de Arqueología Americana 1:9-32.

CINQ-MARS, J., and LAURIOL, B. 1985. Le karst de Tsi-it-tohchoh: Notes préliminaires sur quelques phénomènes karstiques du Yukon septentrional. Annales de la Société Géologique de Belgique 108:185-195.

CINQ-MARS, J., and MORLAN, R.E. In press. Bluefish Caves and Old Crow Basin: A new rapport. Corvallis, Oregon: Peopling of the Americas Publications, Center for the Study of the First Americans, University of Oregon, Corvallis.

CRÉGUT-BONNOURE, E. 1992. Dynamics of bovid migration in western Europe during the Middle and Late Pleistocene. Courier Forschungsinstitut Senckenberg 153:177-185.

CRÉGUT-BONNOURE, E., and GAGNIÈRE, S. 1981. Sur la présence de Saiga tatarica (Mammalia, Artiodactyla) dans le dépôt pléistocène supérieur de la grotte de la Salpêtrière à Remoulins (Gard, France). Nouvelles archéologiques du Musée d'Histoire naturelle de Lyon 19 (Suppl.):37-42.

CURRANT, A.P. 1987. Late Pleistocene saiga antelope Saiga tatarica on Mendip. Proceedings of the University of Bristol Spelaeological Society 18:74-80.

FORMOSOV, A.N. 1963. Snow cover as an integral factor of the environment and its importance in the ecology of mammals and birds. Boreal Institute, University of Alberta, Occasional Paper $1.176 \mathrm{p}$.

FRICK, C. 1937. Horned ruminants of North America. Bulletin of the American Museum of Natural History 69. 699 p.

FYLES, J.G. 1966. Quaternary stratigraphy, Mackenzie Delta and Arctic Coastal Plain. Geological Survey of Canada Paper 661:30-31.

GRAY, D.R. 1987. The muskoxen of Polar Bear Pass. Markham, Ontario: Fitzhenry and Whiteside.

GROMOVA, V.I., ed. 1968. Saiga. In: Fundamentals of paleontology. Vol. 13, Mammals. Jerusalem: Israel Program for Scientific Translations. 539-540.

GUTHRIE, R.D. 1982. Mammals of the mammoth steppe as paleoenvironmental indicators. In: Hopkins, D.M., Matthews, J.V., Jr., Schweger, C.E., and Young, S.B., eds. Paleoecology of Beringia. New York: Academic Press. 307-326.

HARINGTON, C.R. 1961. History, distribution and ecology of the muskoxen. M.Sc. thesis. Montreal: McGill University. . 1971. Ice age mammals in Canada. Arctic Circular 22:66-89. 1980. Radiocarbon dates on some Quaternary mammals and artifacts from northern North America. Arctic 33:815-832. 1981. Pleistocene saiga antelopes in North America and their paleoenvironmental implications. In: Mahaney, W.C., ed. 
Quaternary paleoclimate. Norwich: University of East Anglia, Geo Books. 193-225.

1989. Pleistocene vertebrate localities in the Yukon. In: Carter, L.D., Hamilton, T.D., and Galloway, J.P., eds. Late Cenozoic history of the interior basins of Alaska and the Yukon. U.S. Geological Survey Circular 1026:93-98.

. 1990. Arctic bison. Biome 10(2):4.

1991. Unpubl. field notes. Available at the Canadian Museum of Nature (Paleobiology) Ottawa, Ontario K1P 6P4, Canada.

- In press. Pleistocene vertebrates of Sixtymile, Yukon Territory: A preliminary discussion. In: Edwards, M.E., and Sher, A.V., eds. Common problems in Beringian Quaternary terrestrial studies.

HARINGTON, C.R., and MORLAN, R.E. 1992. A late Pleistocene antler artifact from the Klondike District, Yukon Territory, Canada. Arctic 45:269-272.

HEPTNER, V.G., NASIMOVICH, A.A., and BANNIKOV, A.G. 1988. Mammals of the Soviet Union. Vol. 1. Washington, D.C.: Smithsonian Institution Libraries and National Science Foundation.

HILLABY, J. 1969. Saga of the saiga. Animal Kingdom 72:24-27.

HOPKINS, D.M. 1972. The paleogeography and climatic history of Beringia during late Cenozoic time. Inter-Nord 12:121-150.

KAHLKE, R.-D. 1991. Pleistocene distributional and evolutionary history of the genus Saiga Gray, 1843 (Mammalia, Artiodactyla, Bovidae) in the Palaearctic. Vertebrata PalAsiatica 29(4):314-322. - 1992. Repeated immigration of Saiga into Europe. Courier Forschungsinstitut Senckenberg 153:187-195.

MacDONALD, S.D. 1954. Report on biological investigations at Mould Bay, Prince Patrick Island, Northwest Territories in 1952. Annual Report of the National Museum of Canada, 195253, Bulletin 132:214-238.

MATTHEWS, J.V., Jr. 1982. East Beringia during Late Wisconsin time: A review of the biotic evidence. In: Hopkins, D.M., Matthews, J.V., Jr., Schweger, C.E., and Young, S.B., eds. Paleoecology of Beringia. New York: Academic Press. 127-150.

MELDGAARD, M. 1986. The Greenland caribou—zoogeography, taxonomy, and population dynamics. Meddelelser om Grønland, Bioscience 20.88 p.
MORLAN, R.E. 1989. Paleoecological implications of Late Pleistocene and Holocene microtine rodents from the Bluefish Caves, northern Yukon Territory. Canadian Journal of Earth Sciences 26:149-156.

MORLAN, R.E., and CINQ-MARS, J. 1982. Ancient Beringians: Human occupations in the late Pleistocene of Alaska and the Yukon Territory. In: Hopkins, D.M., Matthews, J.V., Jr., Schweger, C.E., and Young, S.B., eds. Paleoecology of Beringia. New York: Academic Press. 353-381.

PORTER, L. 1988. Late Pleistocene fauna of Lost Chicken Creek, Alaska. Arctic 41:303-313.

RAMPTON, V.N. 1988. Quaternary geology of the Tuktoyaktuk coastlands, Northwest Territories. Geological Survey of Canada Memoir 423.

RITCHIE, J.C. 1984. Past and present vegetation of the far northwest of Canada. Toronto: University of Toronto Press.

RITCHIE, J.C., CINQ-MARS, J., and CWYNAR, L.C. 1982. L'environnement tardiglaciaire du Yukon septentrional, Canada. Géographie physique et Quaternaire 36:241-250.

SHER, A.V. 1968. Fossil saiga in northeastern Siberia and Alaska. International Geology Review 10:1247-1260.

SOKOLOV, V. 1974. Saiga tatarica. Mammalian Species 38:1-4. THENIUS, E., and HOFER, H. 1960. Stammesgeschichte der Säugetiere. Berlin: Springer-Verlag.

VERESHCHAGIN, N.K., and BARYSHNIKOV, G.F. 1982. Paleoecology of the mammoth fauna in the Eurasian Arctic. In: Hopkins, D.M., Matthews, J.V., Jr., Schweger, C.E., and Young, S.B., eds. Paleoecology of Beringia. New York: Academic Press. 267-279.

VIBE. C. 1954. Problemer omkring Grønlandsmoskusoksen. Saetryk af Tiddskrift Grønland 2:401-414.

- 1967. Arctic animals in relation to climatic fluctuations. Meddelelser om Grønland 170. 227 p.

VOGEL, J.S., BROWN, T.A., SOUTHON, J.R., and NELSON, D.E. 1991. Accelerator radiocarbon dates from the NOGAP Archaeology Project. Canadian Archaeological Association Paper No. 1. 143-147. 